\title{
P86 - Magnesium sulphate in the management of severe asthma and atelectasis
}

\author{
Davendralingam Sinniah \\ From 3rd Pediatric Allergy and Asthma Meeting (PAAM) \\ Athens, Greece. 17-19 October 2013
}

\section{Introduction}

Magnesium sulphate (MS), causes bronchodilation by inhibiting bronchial smooth muscle contraction, interferes with parasympathetic stimulation, and prevents acetylcholine release to axon terminals [1]. It reduces inflammation by inhibiting mast cell degranulation and reduces thromboxane, histamine and leukotrienes [2]. Some pediatric studies suggest that MS, b-2-agonists and steroids are beneficial in acute moderate/severe asthma by reducing hospitalization and absolute risk [3].

\section{Objectives}

This paper 1) reviews the randomized controlled trials in the literature on use of MS in asthma and 2) reports the dramatic resolution of massive pulmonary atelectasis in an asthmatic child within 2 hours of IV MS.

\section{Case Report}

A 5-year-old boy with past asthma presented with rapidly progressing asthma unrelieved by prednisolone and multiple doses of salbutamol, ipratropium bromide. Examination revealed tachypnea, tachycardia, chest recession, tracheal tug, right tracheal deviation, dullness and decreased breath sounds in right lower chest and wheezing in other areas. Percutaneous Spo2 was 86\% (room air) and $95 \%$ with oxygen $5 \mathrm{~L} /$ minute. WBC $27.3 \mathrm{x}$ $10^{\wedge} 9 / \mathrm{L}$, neutrophils $25.7 \times 10^{\wedge} 9 / \mathrm{L}$, lymphocytes $1.1 \times 19^{\wedge} 9 / \mathrm{L}$. CRP was $11.6(<10 \mathrm{mg} / \mathrm{L})$. Chest $\mathrm{x}$-ray confirmed atelectasis of right middle and lower lobes. Antibiotics were started followed by IV methylprednisone $(1 \mathrm{mg} / \mathrm{kg})$, aminophylline (10 $\mathrm{mg} / \mathrm{kg}$ bolus), and MS $(50 \mathrm{mg} / \mathrm{kg})$. Chest findings normalized within 2 hours. Spo 2 improved to $95 \%$ on 2 L oxygen/minute. Medication was discontinued save for salbutamol PRN,

International Medical University Clinical School Seremban, Seremban, Malaysia

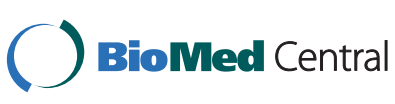

(c) 2014 Sinniah; licensee BioMed Central Ltd. This is an Open Access article distributed under the terms of the Creative Commons Attribution License (http://creativecommons.org/licenses/by/2.0), which permits unrestricted use, distribution, and reproduction in any medium, provided the original work is properly cited. The Creative Commons Public Domain Dedication waiver (http://creativecommons.org/publicdomain/zero/1.0/) applies to the data made available in this article, unless otherwise stated. oral prednisolone $(1 \mathrm{mg} / \mathrm{kg} /$ day $)$, and MDI fluticasone $50 \mathrm{mcg}(\mathrm{BD})$. On day 2 , the child was active and playful. Chest examination and repeat chest $\mathrm{x}$-ray were normal.

\section{Conclusion}

Review of literature and dramatic resolution of asthmarelated massive atelectasis following intravenous MS in our case establishes MS as an adjunct to standard therapy in patients with severe, acute asthma including atelectasis.

Published: 28 February 2014

doi:10.1186/2045-7022-4-S1-P141

Cite this article as: Sinniah: P86 - Magnesium sulphate in the

management of severe asthma and atelectasis. Clinical and Translational Allergy 2014 4(Suppl 1):P141.

Submit your next manuscript to BioMed Central and take full advantage of:

- Convenient online submission

- Thorough peer review

- No space constraints or color figure charges

- Immediate publication on acceptance

- Inclusion in PubMed, CAS, Scopus and Google Scholar

- Research which is freely available for redistribution 